\title{
Genetic Hypothyroid Mice: Normal Cerebellar Morphology but Altered Glycerol-3-Phosphate Dehydrogenase in Bergmann Glia
}

\author{
Tetsuro Sugisaki, ${ }^{1}$ Tetsuya Noguchi, ${ }^{1}$ Wesley G. Beamer, ${ }^{2}$ and Leslie P. Kozak ${ }^{2}$ \\ 'Department of Physiology, Toho University School of Medicine, Ohmori-Nishi, Tokyo-143, Japan and ${ }^{2}$ The Jackson \\ Laboratory, Bar Harbor, Maine 04609
}

\begin{abstract}
The present study was undertaken to investigate the effects of thyroid deficiency on cerebellar development with mouse endocrine genetic models. Four types of mutant mice, the growth hormone- and thyroid hormone-deficient Snell dwarf mouse $(d w / d w)$, the growth hormone-deficient little mouse (lit/lit), the primary hypothyroid mouse (hyt/hyt), and the congenital goiter mouse $(\mathrm{cog} / \mathrm{cog})$ were analyzed for expression of the glial enzyme marker glycerol-3-phosphate dehydrogenase (GPDH) and several other marker proteins. GPDH expression, as determined by enzyme activity and Northern blot analysis, was reduced by about $50 \%$ in the cerebellum and brainstem of the three hypothyroid mutant mice. No reduced expression was found in any region of the brain of the growth hormone-deficient lit/lit mutant. Visualization of GPDH by immunohistology showed that the immunoreactive enzyme was strikingly reduced in the Bergmann glial cells of $d w / d w$, hyt/hyt, and $\operatorname{cog} / \operatorname{cog}$ mutant mice, particularly in the radial glial processes. To evaluate the specificity of the effect on GPDH expression, we also examined the expression of the glial cell-specific S-100 protein by immunohistology. In all mutant cerebella, both the intensity and pattern of staining of the Bergmann glial cells were indistinguishable from that of normal controls, suggesting that the Bergmann glial cells are morphologically normal in the hypothyroid mice. The morphology of the Purkinje cell neurons was similarly visualized by immunohistology using an antiserum specific for the microtubule-associated proteins. Surprisingly, the morphology of the Purkinje cell dendritic arborization also appeared unaltered in the hypothyroid mice. The results suggest that the morphological development of the mouse cerebellum is relatively unaffected by hypothyroidism. However, since GPDH expression is selectively altered in hypothyroid mice, it is likely that the Gdc-1 gene is unusually sensitive to the subtle effects of hypothyroidism in the mouse brain.
\end{abstract}

Hypothyroidism in mammals causes a retardation in the morphological development of several areas of the brain (Delange, 1981), which can be reversed if thyroid hormone is administered during the critical phases of early development (Smith et al., 1957; Levine and Mullins, 1966). In order to understand the

\footnotetext{
Received Aug. 14, 1990; revised Feb. 27, 1991; accepted Mar. 4, 1991.

This research was partially supported by the Toho University School of Medicine and by Grant 63-A from the National Center for Neurology and Psychiatry of the Ministry of Health and Welfare, Japan, and by U.S. Public Health Service NIH Grant HD06712. The Jackson Laboratory is fully accredited by the American Association for Accreditation of Laboratory Animal Care.

Correspondence should be addressed to Dr. Kozak at the above address.

Copyright (C) 1991 Society for Neuroscience $0270-6474 / 91 / 112614-08 \$ 03.00 / 0$
}

molecular mechanisms underlying thyroid hormone action in the developing brain, extensive biochemical analyses have been carried out on thyroid hormone-deficient rats (Dussault and Ruel, 1987). Reductions have been observed in total RNA and protein content of the cerebrum and cerebellum (Balázs et al., 1968), as well as in the activity levels for specific enzymes associated with energy metabolism (Hamburgh and Flexner, 1957; Schwark et al., 1972), myelination (Balázs et al., 1969; Noguchi and Sugisaki, 1984), microtubule formation (Fellous et al., 1979), and neurotransmitter metabolism (Rastagi and Singhal, 1979; Patel et al., 1980; Smith et al., 1980), However, we do not know whether any of these differences are primary or whether they reflect secondary effects on brain cell development.

The effects of thyroid hormone deficiency on CNS morphogenesis are clearly evident in the cerebellum (Legrand, 1979). The Purkinje cell neurons are in a pivotal position in the developing cerebellum. As evidenced from the cerebellar mutants in the mouse, the position and number of the Purkinje cells are essential for the subsequent establishment of synaptic connections in the molecular layer and for properly positioning the granule cell neurons (Sidman, 1974). The major defect in the cerebellum of hypothyroid rats involves the Purkinje cells. Both the position and number of the Purkinje cells are normal, but they have a stunted dendritic tree (Legrand, 1979). Consequently, the Purkinje cell neurons cannot establish a normal complement of synaptic contacts with the granule cell neurons and a permanent impairment of neuronal connectivity results. These abnormalities can be reversed if treatment with thyroid hormone is given before the critical period of cerebellar development, i.e., before $21 \mathrm{~d}$ of age in the rat (Eayrs, 1960). However, the primary targets of thyroid hormone action that are required for morphogenesis in the CNS are still unknown.

The degenerative loss of Purkinje cell neurons or their abnormal positioning has a major effect on expression of $G d c-1$, the structural gene for glycerol-3-phosphate dehydrogenase (EC 1.1.1.8; GPDH), in Bergmann glial cells (Fisher and Mullen, 1988). Since the majority of cerebellar GPDH expression in the mouse is localized to the Bergmann glial cells (Fisher et al., 1981), we have attempted to determine the effects of abnormal Purkinje cell morphology, expected to be present in genetically hypothyroid mice, on regulation of GPDH expression in the cerebellum. Understanding the molecular basis of this interaction could help us to determine a specific site for thyroid hormone action in the cerebellum.

\section{Materials and Methods}

Animals. Four endocrine mutant mice with the following hormonal deficiencies were studied: (1) The Snell dwarf $(d w / d w)$ mouse is char- 

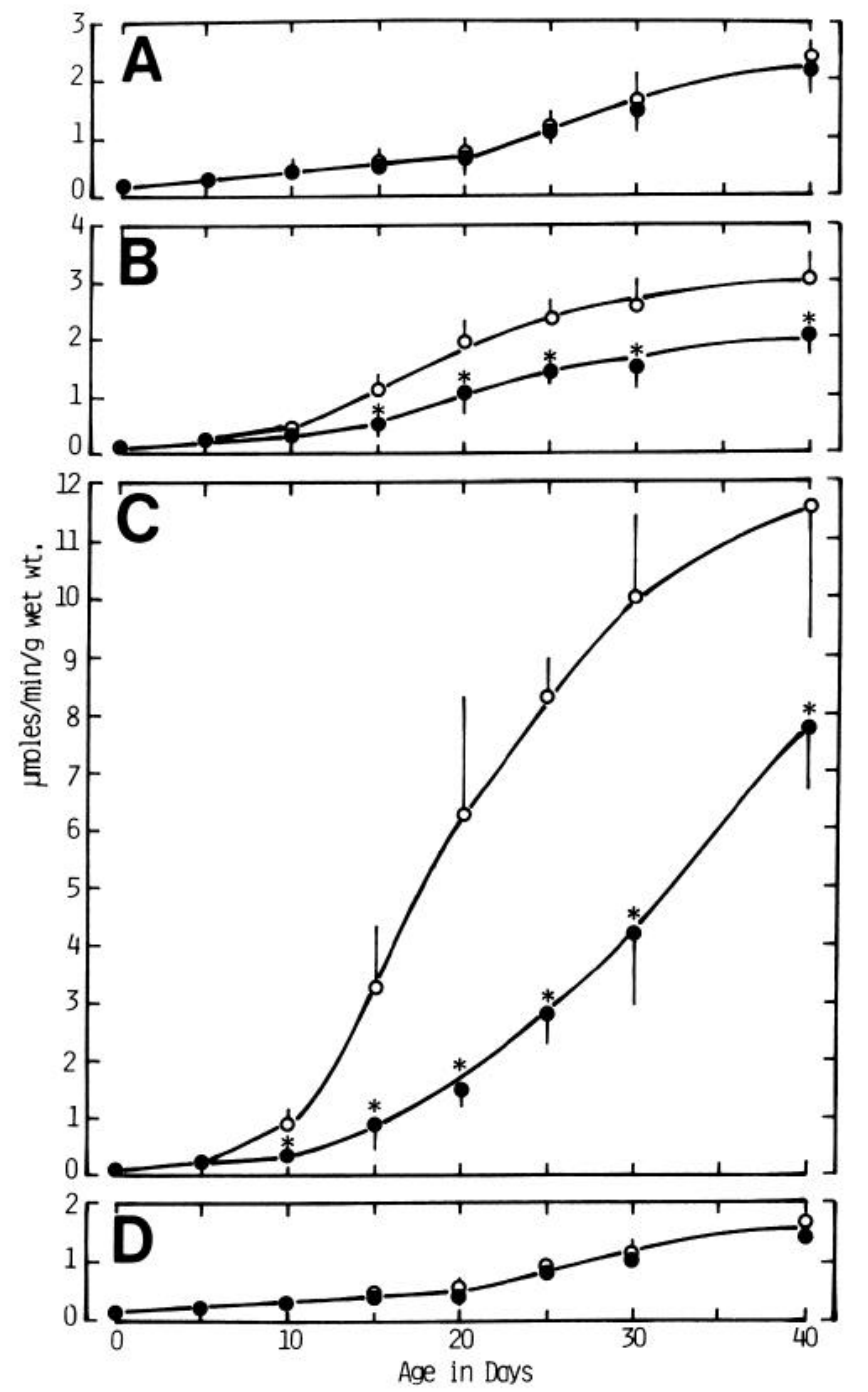

Figure 1. Ontogenetic changes in GPDH activity in the brain of hyt mice. $A$, Cerebrum; $B$, brainstem; $C$, cerebellum; $D$, olfactory bulb. $O$, hyt/+ mice; , hyt/hyt mice. Each point represents the mean of at least six animals. Vertical lines represent 1 SD. The statistical significance of differences between groups at $p<0.01$ is indicated by the asterisks. Comparable differences were observed in the developmental curve of the $d w / d w$ mice, while no differences from control littermates were observed in the lit/lit mutant mice.

acterized by severely retarded somatic growth and undetectable growth hormone (GH), thyroxine (T4), and triiodothyronine (T3), as well as decreased gonadotropin and corticosterone (Eicher and Beamer, 1980). (2) The hypothyroid (hyt/hyt) mouse is characterized by retarded somatic growth, undetectable serum T4 and T3, and elevated thyroid stimulating hormone (TSH) levels (Beamer et al., 1981). (3) The congenital goiter $(\operatorname{cog} / \mathrm{cog})$ mouse is characterized by a moderately reduced rate of growth, reduced serum T4 and T3 levels, and elevated serum TSH (Beamer et al., 1987). (4) The little (lit/lit) mouse is characterized by retarded somatic growth, very low to undetectable GH (Eicher and Beamer, 1976), but increased serum T4 and corticosterone levels (W. G. Beamer, unpublished observations). All mice were raised in research colonies at The Jackson Laboratory and at Toho University. Mice were fed Wayne sterilizable rodent Blox food pellets ( $24 \%$ crude protein, $4 \%$ fat, $4.5 \%$ fiber, $5.9 \%$ ash, fortified with vitamins and minerals; Tekland/ Primer Laboratory Diets, Bartonville, IL) and had free access to chlorinated (10-20 ppm sodium hypochlorite) water. Mice were housed in small groups of the same sex in plastic cages on sterilized white pine shavings. Animal rooms were maintained at $20-23^{\circ} \mathrm{C}$ with a 12 -hr light/ dark cycle. The experimental animals were killed at 6 weeks of age. The
(A)

GPDH MRNA

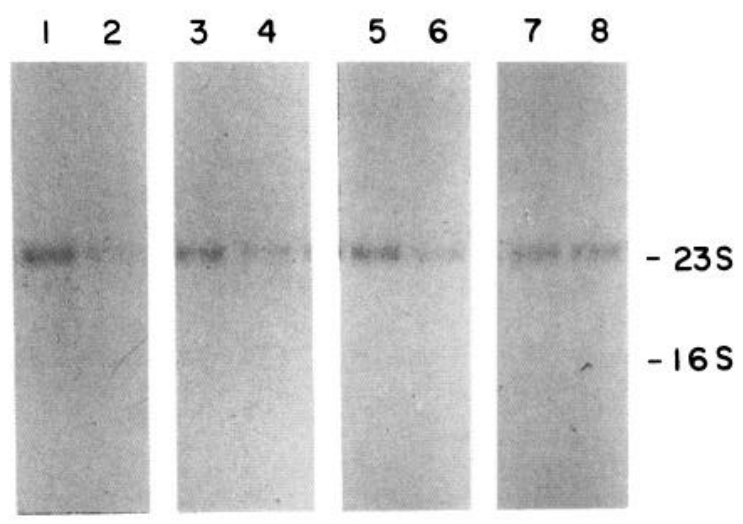

(B)

a-Tubulin mRNA

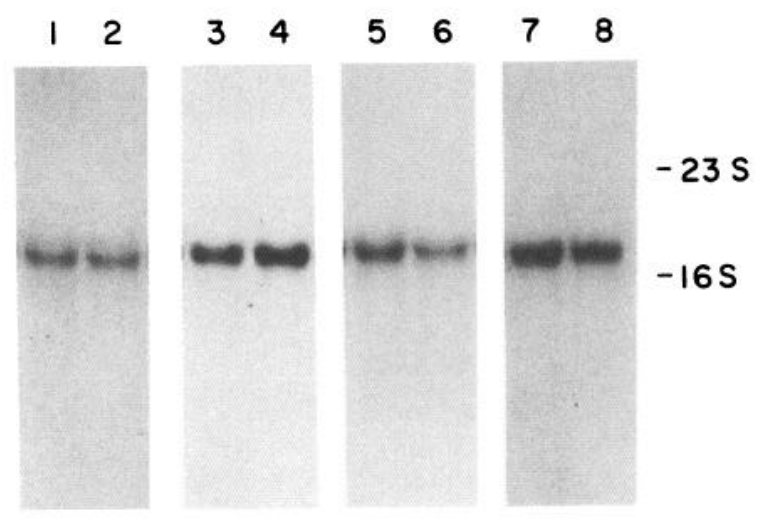

Figure 2. Northern blot analysis of (A) GPDH and $(B) \alpha$-tubulin mRNA levels in the cerebellum of Snell dwarf $(d w / d w)$, hypothyroid (hyt/hyt), congenital goiter $(\operatorname{cog} / \mathrm{cog})$, and little (lit/lit) mice. Lanes: $1,+/ ? ; 2, d w /$ $d w ; 3$, hyt/+; 4, hyt/hyt; 5, $\operatorname{cog} /+; 6, \operatorname{cog} / \operatorname{cog} ;$ 7, lit/+; 8, lit/lit.

brain and other tissues were removed, and brain regions were dissected as described by Glowinski and Iversen (1966).

Biochemical estimations. GPDH and lactate dehydrogenase (LDH) activities were measured on $100,000 \times g$ supernatant fractions as previously described (Kozak and Jensen, 1974). Iodothyronine 5'-deiodinase activity was carried out essentially as described by Leonard et al. (1981). Reactions were carried out with $100,000 \mathrm{cpm}$ of ${ }^{125} \mathrm{I}_{-} \mathrm{T}_{4}$ (New England Nuclear) plus unlabeled T4 to give the indicated concentrations of substrate in $0.20 \mathrm{ml}$ of $100 \mathrm{~mm}$ potassium phosphate, $1 \mathrm{~mm}$ EDTA (pH 7.0), containing $20 \mathrm{~mm}$ dithiothreitol. Protein concentration was determined as described by Bradford (1976). Crystalline bovine serum albumin was used as the standard.

Isolation of RNA and Northern blot analysis was performed as described by Jacobsson et al. (1985). The GPDH probe was a DNA fragment containing exon 2 of the mouse $G d c-1$ gene (Ireland et al., 1986) and the $\alpha$-tubulin probe was a human cDNA fragment (Davis et al., 1987). Both probes were labeled with ${ }^{32} \mathrm{P}$-dCTP by nick-translation.

Immunohistochemistry. Bovine $\mathrm{S}-100$ protein was purified according to the method of Isobe et al. (1977). Antiserum was obtained from New Zealand White rabbits injected with $10 \mathrm{mg}$ of S-100 protein-bovine serum albumin complex in Freund's complete adjuvant, followed by biweekly inoculations of $5 \mathrm{mg}$ of complex in Freund's complete adjuvant for 2 months. Anti-GPDH antibody was produced as previously described (Fisher et al., 1981). Anti-microtubule-associated protein (MAPS) antiserum was purchased from Sigma Chemical Co., St. Louis, MO (product M-7273). Anti-MAPS antiserum stains mainly MAP2 and to a lesser extent the TAU bands using an immunoblot method.

Six-week-old mutant and control mice were killed by perfusion through 

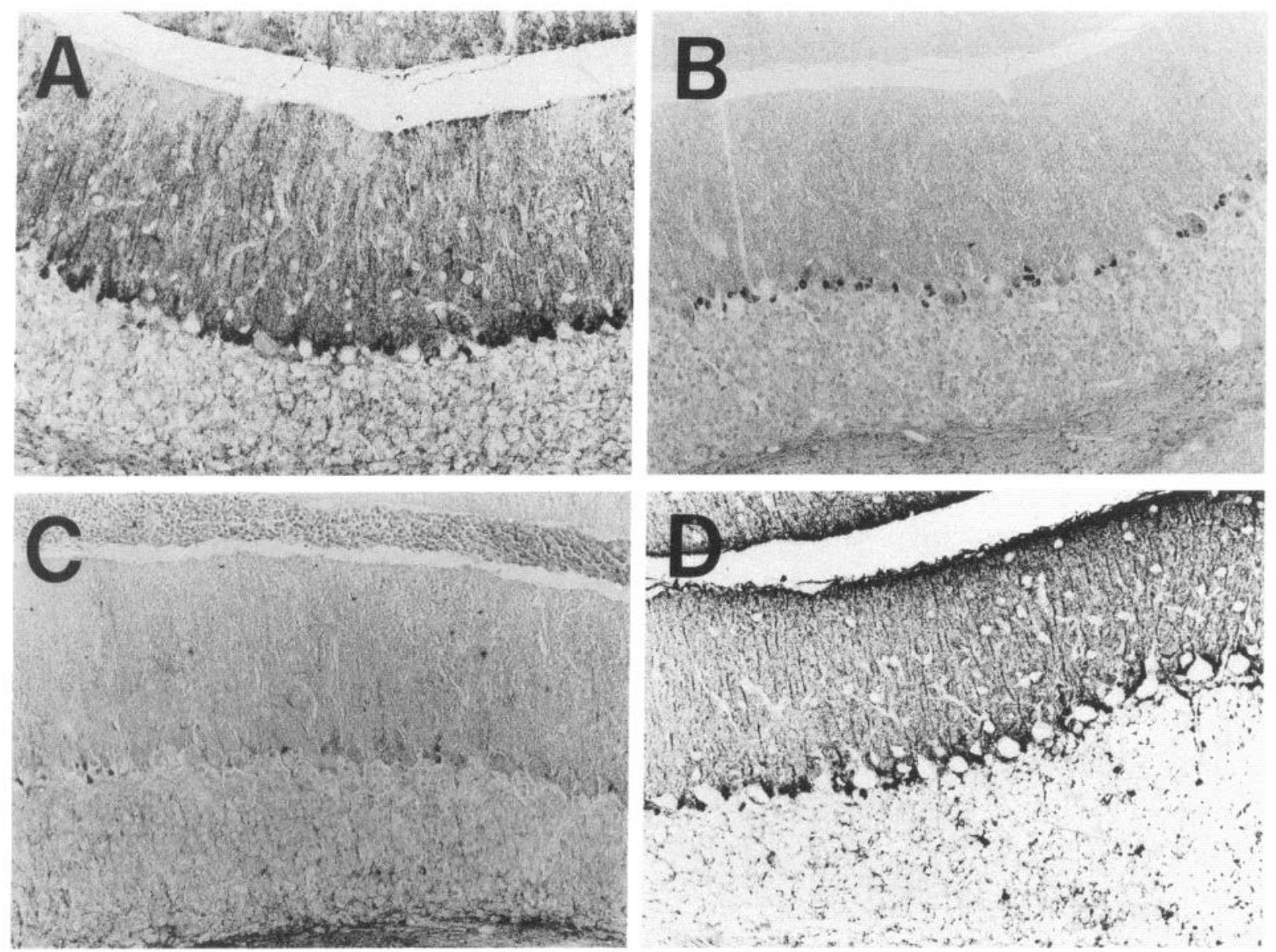

Figure 3. Localization of GPDH in the cerebellum of control and mutant mice. $A$, hyt/+. B, hyt/hyt Bergmann glia cells contain immunoreactive enzyme in cell bodies, but not in fibers. $C, d w / d w$ Bergmann glia cells do not contain immunoreactive enzyme in either cell bodies or fibers. $D$, lit/lit Bergmann glia cells contain immunoreactive enzyme in both cell bodies and fibers. Magnification, $50 \times$. Littermate controls were also run with $d w / d w$ and lit/lit samples; however, results are not shown because they were indistinguishable from $h y t /+$.

the heart with ice-cold $0.01 \mathrm{M}$ phosphate-buffered saline followed by ice-cold Bouin's solution. Following a 30 -min fixation in situ at $4^{\circ} \mathrm{C}$, the brains were removed and postfixed with Bouin's solution for $3 \mathrm{~d}$ at $4^{\circ} \mathrm{C}$. Paraffin-embedded brain samples were sectioned at $4 \mu \mathrm{m}$ and stained for GPDH and S-100 protein at 1:1000 antisera dilution using an avidin-biotin-horseradish peroxidase staining kit (Vector Laboratories Inc., Burlingame, CA).

For the immunohistochemistry of MAPS, sagitally sectioned cerebella were fixed overnight in $4 \%$ paraformaldehyde and $0.1 \%$ glutaraldehyde in $0.1 \mathrm{M}$ phosphate buffer, $\mathrm{pH}$ 7.6. After washing in phosphate buffer, $50-\mu \mathrm{m}$ Vibratome sections were immunohistochemically stained at antiserum dilutions of $1: 200$.

Statistics. Statistical significance of differences between means was determined by Student's $t$ test.

\section{Results}

\section{GPDH enzyme activity in hypothyroid mice}

The ontogenetic changes in activity of GPDH in four regions of the brain of hyt/hyt mice (cerebrum, brain stem, cerebellum, and olfactory bulbs) are shown in Figure 1. In normal mice, the pattern of activity was similar to that previously described for the rat and mouse (Laatsch, 1962; Kozak, 1972). During postnatal development, GPDH activity was depressed in the brainstem and cerebellum of $h y t / h y t$ mice (Fig. $1 B, C$ ) but not in the cerebrum and olfactory bulbs (Fig. $1 A, D$ ). Virtually identical results were also observed with $d w / d w$ mice; however, no re- duction in GPDH activity was detected in any brain region of lit/lit mice (data not shown).

The analysis of mice at $40 \mathrm{~d}$ of age was extended to include several brain regions. The spinal cord and the striatum showed reductions in activity comparable to that detected in the brainstem of $d w / d w$ and hyt/hyt mice; however, the frontal cortex, hippocampus, hypothalamus, and thalamus did not show a reduction in activity in any of the mutants. Mice homozygous for the $\operatorname{cog}$ mutant allele are also hypothyroid and were identical to hyt/hyt mice in their pattern of expression. As a control to evaluate whether the hypothyroidism might cause a generalized depression in enzyme activity in the cerebellum, LDH was assayed in all samples, and in no case was any reduction in enzyme activity observed (Table 1).

\section{$m R N A$ levels}

To evaluate the mechanism by which hypothyroidism results in reduced levels of GPDH enzyme activity in the cerebellum, mRNA levels were estimated by Northern blot analysis. GPDH mRNA levels were reduced by about $50 \%$ in the three hypothyroid mutants but remained unchanged in growth hormonedeficient lit/lit mice (Fig. 2). In contrast, the levels of $\alpha$-tubulin mRNA were unchanged in both the hypothyroid- and growth 

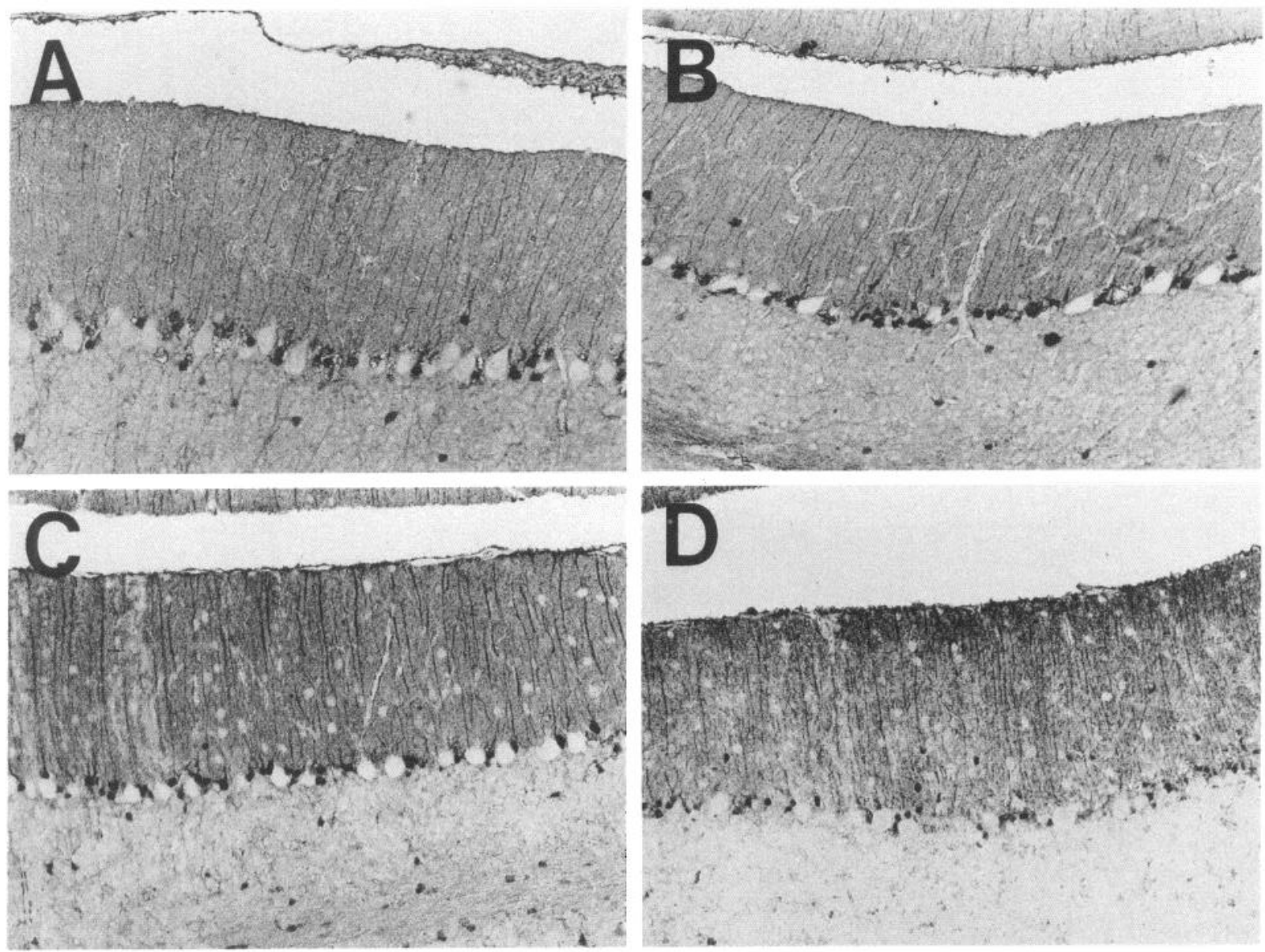

Figure 4. Localization of S-100 protein in the cerebellum of control and mutant mice. $A, h y t /+; B, h y t / h y t ; C, d w / d w ; D, l i t / l i t$. Magnification, $50 \times$.

hormone-deficient mice, suggesting that the reduction was specific for GPDH mRNA and possibly other unknown gene products.

\section{Immunohistology}

$G P D H$. Figure 3 illustrates the immunoperoxidase localization of GPDH in the cerebellum of normal and mutant mice. In the normal cerebellum, an intense positive staining reaction occurred in cell bodies clustered within the Purkinje cell layer and fibers that radiated to the surface of the cortex. This pattern of staining is characteristic for the Golgi epithelial cells and their Bergmann fibers (Palay and Chan-Palay, 1974). In contrast, no positive staining reaction occurred in either cell bodies or fibers of the cerebellum of $d w / d w$ mice (Fig. 3C). In the hyt/hyt cer-

Table 1. Cerebellar GPDH and LDH activities (nmol/mg protein/min) of mouse endocrine mutants

\begin{tabular}{llllll} 
& Females & & & Males \\
\cline { 2 - 3 } \cline { 5 - 6 } Genotype & GPDH & LDH & & GPDH & LDH \\
\hline$+/ ?$ & $455 \pm 46$ & $1285 \pm 164$ & & $426 \pm 70$ & $1261 \pm 241$ \\
$d w / d w$ & $182 \pm 34$ & $1321 \pm 266$ & & $175 \pm 35$ & $1341 \pm 291$ \\
& $(40 \%)^{*}$ & $(103 \%)$ & & $(41 \%)^{*}$ & $(106 \%)$ \\
$h y t /+$ & $585 \pm 118$ & $1665 \pm 278$ & & $495 \pm 85$ & $1362 \pm 393$ \\
$h y t / h y t$ & $287 \pm 47$ & $1947 \pm 464$ & & $215 \pm 42$ & $1541 \pm 466$ \\
& $(49 \%)^{*}$ & $(117 \%)$ & & $(43 \%)^{*}$ & $(113 \%)$ \\
$\operatorname{cog} /+$ & $317 \pm 16$ & $1725 \pm 242$ & & $371 \pm 17$ & $1638 \pm 436$ \\
$\operatorname{cog} / \operatorname{cog}$ & $199 \pm 21$ & $1824 \pm 119$ & & $196 \pm 29$ & $1733 \pm 315$ \\
& $(63 \%)^{*}$ & $(106 \%)$ & & $(53 \%)^{*}$ & $(106 \%)$ \\
lit/ & $386 \pm 75$ & $1860 \pm 423$ & & $419 \pm 19$ & $2024 \pm 112$ \\
lit/lit & $375 \pm 62$ & $1854 \pm 358$ & & $415 \pm 29$ & $2008 \pm 172$ \\
& $(97 \%)$ & $(100 \%)$ & $(99 \%)$ & $(99 \%)$ \\
\hline
\end{tabular}



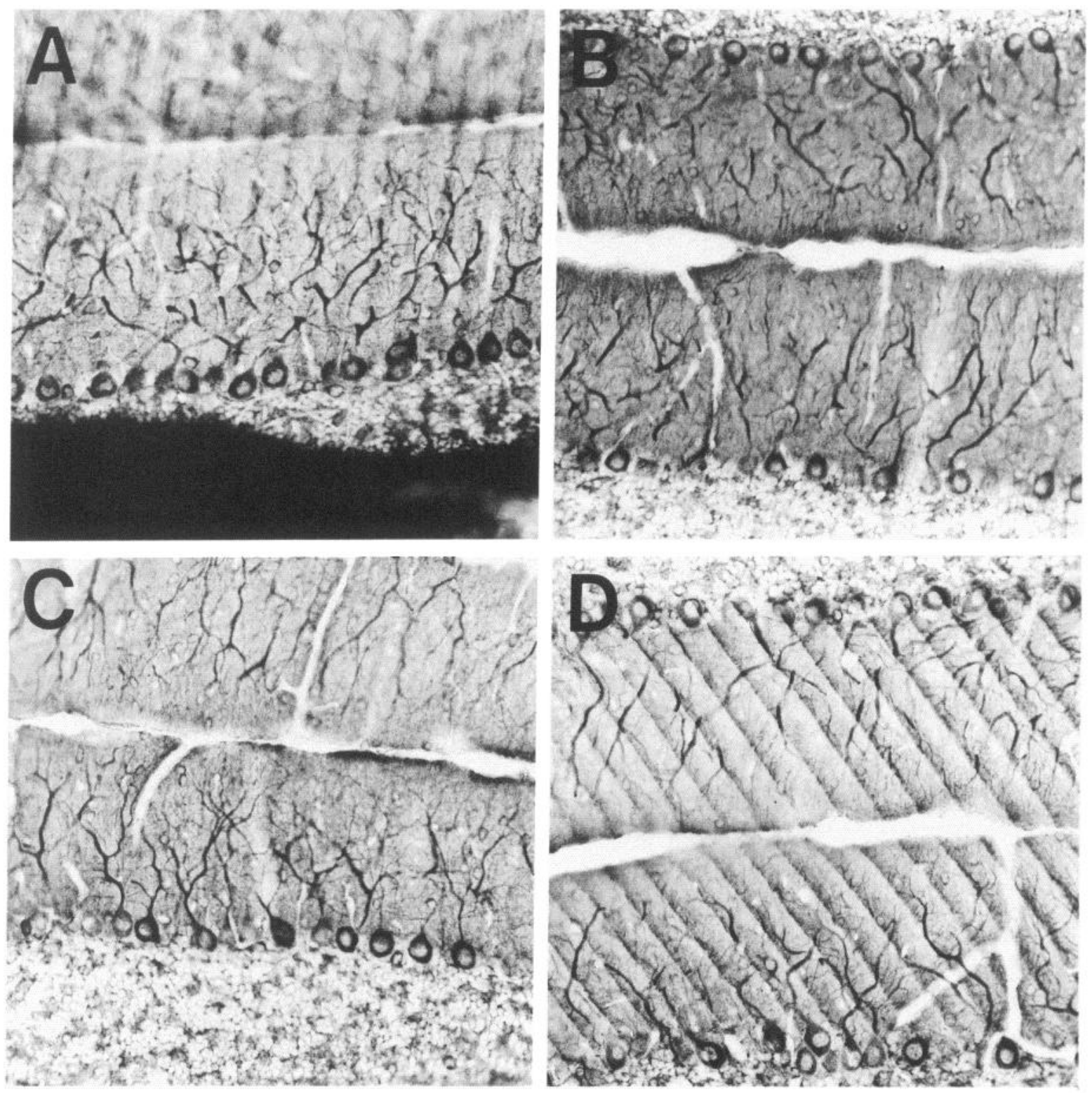

Figure 5. Immunostaining of MAP2 in the cerebellum of control and mutant mice. $A, h y t /+; B, h y t / h y t ; C, d w / d w ; D, l i t / l i t$. Magnification, $50 \times$.

ebellum, no positive reaction occurred in fibers, although the cell bodies of the Bergmann glia stained lightly for GPDH. On the other hand, the cell bodies and radial fibers in the cerebellum of growth hormone-deficient lit/lit mice stained intensely for GPDH and were indistinguishable from those of the normal controls in organization and appearance (Fig. $3 D$ ).

$S-100$ protein. To evaluate whether the reductions in GPDH immunohistology reflect major abnormalities in the Bergmann glial cells, the S-100 protein, a glial cell marker (Matus and Mughal, 1975), was also localized by immunohistology. Both the cell bodies and radial fibers of the Bergmann glial cells in the mutant cerebella stained intensely, and they were indistinguishable from the control sections (Fig. 4). Accordingly, neither the structure of the cells nor their ability to synthesize the S-100 protein is affected by hypothyroidism.

Microtubule-associated proteins. In order to visualize the arborization of Purkinje cell dendrites, we immunohistochemi- cally stained vibratome sections of cerebella for MAP2 (Caceres et al., 1984; Huber and Matus, 1984). An intense positive staining reaction for MAP2 occurred in Purkinje cell bodies and in the dendrites that extended to the cortical surface. The staining intensity, the extent of the dendritic processes, and the organization of the Purkinje cells in the hypothyroid mice were indistinguishable from those of the control mice (Fig. 5). This result indicates that retardation of the growth and development of Purkinje cell neurons in hypothyroid mice is not visually apparent with immunohistology.

\section{Iodothyronine 5'-deiodinase}

The hypothyroid rat responds to its altered thyroxine status with a two- to fourfold elevation of iodothyronine 5 '-deiodinase in the cerebral cortex (Leonard et al., 1981). In the cerebellum of the three genetically hypothyroid mutants, 5 '-deiodinase activ- 
Table 2. Thyroxine 5'-deiodinase activity in cerebellar tissue of Snell dwarf $(d w / d w)$, hypothyroid (hyt/hyt), congenital goiter $(\operatorname{cog} / \operatorname{cog})$, and little (lit/lit) mutant mice

\begin{tabular}{llr} 
& Treatment & \\
\cline { 2 - 3 } Genotype & $\begin{array}{l}\text { Control } \\
\text { (fmol/mg protein/hr) }\end{array}$ & $\begin{array}{l}1 \mathrm{~mm} \text { PTU } \\
\text { (fmol/mg protein/hr) }\end{array}$ \\
\hline$+/ ?$ & $12.0 \pm 2.4$ & $8.5 \pm 4.0(71 \%)$ \\
$d w / d w$ & $26.2 \pm 1.8(218 \%)^{* *}$ & $22.2+17.1(186 \%)$ \\
$h y t /+$ & $6.4 \pm 2.7$ & $5.6 \pm 0.7(88 \%)$ \\
$h y t / h y t$ & $24.5 \pm 3.0(386 \%)^{* *}$ & $20.6 \pm 7.3(324 \%)$ \\
$\operatorname{cog} /+$ & $3.4 \pm 0.8$ & $2.9 \pm 0.5(85 \%)$ \\
$\operatorname{cog} / \operatorname{cog}$ & $14.1 \pm 5.3(420 \%)^{*}$ & $11.1 \pm 2.1(329 \%)$ \\
lit/+ & $10.6 \pm 1.7$ & $8.8 \pm 0.9(84 \%)$ \\
lit/lit & $8.8 \pm 1.7(84 \%)$ & $8.3 \pm 2.5(78 \%)$
\end{tabular}

Results are expressed as means $\pm \mathrm{SD}$, based on four mice per group. The significance of differences between each endocrine mutant and its control littermate was evaluated by the Student's $t$ test $\left({ }^{* *}, p<0.0005 ;{ }^{*}, p<0.01\right)$. PTU is propylthiouracil.

ity was elevated to a similar extent (Table 2). As expected, activity of type 2 deiodinase was resistant to inhibition by propylthiouracil. This result provides important confirmation of the cerebellar response to the hypothryoid status of these mice.

\section{Discussion}

The NAD-linked GPDH catalyzes the synthesis of glycerol phosphate, a precursor for phospholipid synthesis, from glycolytic intermediates (Linn, 1977). Based on this function and the fact that the developmental appearance of GPDH in the brain of rats coincided with the onset of myelination, Laatsch (1962) postulated that GPDH was required for myelination. The immunohistological localization of GPDH to the oligodendroglia of the cerebellum of mice and rats supported this hypothesis (Fisher et al., 1981). Parenthetically, the Bergmann glial cells which elaborate an extensive membrane that ensheaths the Purkinje cell neurons also express high levels of GPDH. When Schwark et al. (1971) subsequently found that neonatal thyroidectomy of the rat resulted in reductions in GPDH in both the cerebrum and cerebellum, they suggested that this reduction in enzyme levels was associated with the defective myelination of the hypothyroid rat. Since we had found reductions in the levels of $2^{\prime}, 3^{\prime}$-cyclic nucleotide 3 '-phosphohydrolase, a myelin marker, in the cerebrum but not the cerebellum of hyt/hyt mice (Noguchi and Sugisaki, 1984), we expected that reductions in GPDH would be found in the cerebrum of $h y t / h y t$ mice. Surprisingly, reductions in GPDH enzyme and mRNA levels were found only in the cerebellum. Accordingly, no correlation exists in genetic hypothyroid mice between myelination and GPDH levels. This finding is in agreement with recent observations that a GPDH-null mutation in mice (Hilgers et al., 1985; Prochazka et al., 1989) causes no detectable abnormalities in myelin structure in the CNS of these mutant mice (L. P. Kozak, unpublished observations).

There is strong evidence that the cerebral cortex of the hypothyroid rat has a reduced myelin content (Rosman et al., 1972). This meylin appears to be normal biochemically and ultrastructurally (Malone et al., 1975). Other quantitative changes include reductions in the number of neurons, axons, and dendritic arborizations. The cerebellum of the hypothyroid rat shows similar changes, the most prominent being the severe stunting of the dendritic arborization of the Purkinje cell neurons and loss of Basket cells (Legrand, 1979). Although many enzymes have reduced expression in the brain of the hypothyroid rat, the severe effects of hypothyroidism are most strikingly illustrated by a $20 \%$ reduction of total protein and RNA levels in the cerebrum and cerebellum relative to DNA (Balázs, 1968; Gourdon et al., 1973). In contrast to the rat, the $h y t / h y t$ mouse shows no reduced protein or RNA levels in either the cerebrum or cerebellum (Noguchi and Sugisaki, 1984). Reductions of approximately $10 \%$ are detected in the $d w / d w$ mouse, but this animal has a combined growth hormone and thyroid hormone deficiency (Sarlieve et al., 1984). Since the lit/lit mouse, which is specifically growth hormone-deficient, has a similar reduction in tissue wet weight and protein, it is most likely that the reductions in $d w / d w$ mice are due to deficiencies in growth hormone and not thyroid hormone. Previously, we showed that the myelin enzyme marker 2',3'-cyclic nucleotide 3 '-phosphohydrolase was reduced by $40 \%$ in the cerebrum of the hyt/hyt mouse but remained unchanged in the cerebellum and brainstem (Noguchi and Sugisaki, 1984). The results in the present study demonstrate that no abnormalities can be detected in the morphology of the Purkinje cell neurons, yet the cerebellum of the $h y t / h y t$ mouse responds to the hypothyroid state by inducing iodothyronine deiodinase in a manner quantitatively similar to the hypothyroid rat. Since these results on Purkinje cell morphology and deiodinase induction are found with the three hypothyroid mouse mutants, we suggest that the observed responses are a general feature of thyroid deficiency in the mouse and not a characteristic of a particular mouse mutant. Thus, morphogenetic development in the mouse cerebellum appears to be surprisingly resistant to the devastating effects of hypothyroidism found in the rat and human.

Although the reductions in GPDH levels in the cerebellum of hypothyroid mice do not explain hypomyelination, they do provide an insight into possible disruptions of ccll-to-cell interactions that may be occurring in the hypothyroid cerebellum and suggest a molecular approach to investigate the problem. The control of GPDH expression during the development of the cerebellum is extremely sensitive to allelic variation among inbred strains of mice and to the cellular milieu of the cerebellum (Kozak and Fisher, 1985). Any mutation that causes a reduction in the number, a change in the position, or an alteration in the structure of Purkinje cell neurons results in a large reduction in GPDH expression at both the protein and mRNA level. Since the Purkinje cell neurons and Bergmann glial cells are in intimate 
contact, these results indicate that expression of the GPDH structural gene in the Bergmann glial cell is dependent on this contact. The characteristics of GPDH expression in hypothyroid mice are virtually identical to those observed previously in mice with cerebellar mutations such as weaver $(w v / w v)$, reeler $(r l / r l)$, nervous $(n r / n r)$, staggerer $(s g / s g)$, and Purkinje cell deficiency $(p c d / p c d)$. In both the cerebellar mutants and the hypothyroid mutants, the reduction in GPDH expression, as measured by activity assays, is approximately $50 \%$ of the control, while the reduction in immunostaining of the Bergmann glial cells is almost complete (see Fig. 4; Fisher et al., 1981; Kozak and Fisher, 1985). We interpret this to mean that GPDH is enriched in Bergmann glial cells where its expression is dependent on the appropriate contact with the Purkinje cell neurons; however, other cell types in the cerebellum also express GPDH, albeit at lower levels, but this expression is not sensitive to interactions with Purkinje cell neurons. This suggests that the underlying mechanism affecting GPDH expression in the cerebellar mutants and in the hypothyroid mutants is similar. Further support for this idea comes from the work of Messer and Hatch (1984), who proposed that cessation of granule neuron proliferation in the external layer is controlled by the Purkinje cell neurons. Delays in the maturation of the Purkinje cells caused by mutational effects intrinsic to the Purkinje cells, e.g., staggerer ( $s g$ / $s g$ ) or hypothyroidism, result in delays in the cessation of proliferation.

Using immunohistology with anti-MAP2 antibodies, a reduction in the size of the Purkinje cell dendritic arborization was observed in the 2-week-old hypothyroid rat that corrected itself by 3 weeks of age (Silva and Rudas, 1990). Immunohistology with anti-MAPS antibodies did not reveal a corresponding abnormality in the dendrites of the Purkinje cells of the hypothyroid mouse at $40 \mathrm{~d}$ of age (Fig. 5). Clos et al. (1982) have reported that hypothyroidism in the rat causes a reduction in the $\mathrm{S}-100$ protein content of the Bergmann glial cells. We could not, however, detect reductions in $S-100$ protein in the hypothyroid mice by immunohistology under staining conditions which readily reveal reductions in GPDH. Thus, neither the Purkinje cell neurons nor the Bergmann glial cells show morphological abnormalities at a time when striking reductions in GPDH expression can be detected.

We have interpreted the lack of biochemical and morphological defects in the cerebellum of genetically hypothyroid mice to be a consequence of resistance in mice to the effects of hypothyroidism. Morphological and biochemical abnormalities have previously been observed in the cerebellum of rats made hypothyroid by treatment with propylthiouracil (Legrand, 1979). One possibility is that this is a species difference in sensitivity to hypothyroidism. Alternatively, since the comparisons have been made between a genetic model and a chemically induced model, it is possible that the method for causing hypothyroidism is the basis for the differences observed. Indeed, the fact that Silva and Rudas (1990) also failed to detect abnormalities in the Purkinje cell neurons of rats made hypothyroid by adding methimazole to the drinking water of pregnant rats suggests that differences in the methods used to establish the hypothroidism may be causing effects independent of hypothyroidism itself. This important problem requires further investigation.

How do we explain the effects on GPDH expression? From the behavior of GPDH expression in neurological mutants of the mouse, we argue that subtle morphological abnormalities, undetected histologically, also exist in the Purkinje cell neurons of the hypothyroid mice. These abnormalities could interfere with normal interactions occurring between Bergmann glial cells and Purkinje cell neurons to reduce the level of GPDH expression. In this view, the primary site of thyroid hormone action is the Purkinje cell neuron, while the effect on GPDH expression in the Bergmann glial cell is secondary. During the preparation of this manuscript, Silva and Rudas (1990) reported that hypothyroidism in rats causes transient reductions in cerebellar MAP2 expression and proposed that this is the indirect result of disruptions in cerebellar cell-to-cell interactions in the hypothyroid rat. Thus, data from both the morphological and molecular experiments continue to indicate that thyroid hormone deficiency impairs the interactions of Purkinje cell neurons with other cells in their environment. Part of the significance of the present work is that it indicates that the analysis of GPDH expression can provide a sensitive molecular probe to evaluate the functional role of thyroid hormone on cell-tocell interactions and gene expression during the development of the cerebellum.

\section{References}

Balázs R, Kovács S, Teichgräber P, Cocks WA, Eayrs JT (1968) Biochemical effects of thyroid deficiency on the developing brain. J Neurochem 15:1335-1349.

Balázs R, Brooksbank BWL, Davison AN, Eayrs JT, Wilson DA (1969) The effect of neonatal thyroidectomy on myelination in the rat brain. Brain Res 15:219-232.

Beamer WG, Eicher EM, Maltais LJ, Southard JL (1981) Inherited primary hypothyroidism in mice. Science 212:61-63.

Beamer WG, Maltais LJ, DeBaets MH, Eicher EM (1987) Inherited congenital goiter in mice. Endocrinology 120:838-840.

Bradford MM (1976) A rapid sensitive method for the quantitation of microgram quantities of protein utilizing the principle of proteindye binding. Anal Biochem 72:248-254.

Caceres A, Binders LL, Payne MR, Bender P, Rebhun L, Steward O (1984) Differential subcellular localization of tubulin and the microtubule-associated protein MAP2 in brain tissue as revealed by immunocytochemistry with mono-clonal hybridoma antibodies. J Neurosci 4:394-410.

Clos J, Legrand C, Legrand J, Ghandour MS, Labourdette G, Vincendon G, Gombos G (1982) Effects of thyroid state and undernutrition on S-100 protein and astroglial development in rat cerebellum. Dev Neurosci 5:285-292.

Davis RC, Thomason AR, Fulleo ML, Slovin JP, Chow C-C, Chada S, Grotti RA, Salser WA (1987) mRNA species regulated during the differentiation of HL-60 cells to macrophages and neutrophils. Dev Biol 119:164-174.

Delange FM (1981) Relation of thyroid hormones to human brain development. In: Fetal brain disorders-recent approaches to the problem of mental deficiency (Hetzel BS, Smith RM, eds), p 285. Amsterdam: Elsevier/North-Holland.

Dussault JH, Ruel J (1987) Thyroid hormones and brain development. Annu Rev Physiol 49:321-334.

Eayrs JT (1960) Influence of the thyroid on the central nervous system. Br Med Bull 16:122-127.

Eicher EM, Beamer WG (1976) Inherited atelotic dwarfism in mice: characteristics of the mutation (lit). J Hered 67:87-91.

Eicher EM, Beamer WG (1980) New mouse $d w$ allele: genetic location and effects on lifespan and growth hormone levels. J Hered 71:187190.

Fellous A, Lennon AM, Francon J, Nunez J (1979) Thyroid hormones and neurotubule assembly in vitro during brain development. Eur $\mathrm{J}$ Biochem 101:365-376.

Fisher M, Mullen RJ (1988) Neuronal influence on glial enzyme expression: evidence from chimeric mouse cerebellum. Neuron 1:151157.

Fisher M, Gapp DA, Kozak LP (1981) Immunohistochemical localization of sn-glycerol-3-phosphate dehydrogenase in Bergmann glia and oligodendroglia in the mouse cerebellum. Brain Res 227:341354. 
Glowinski J, Iverson LL (1966) Regional studies of catecholamine in the rat brain. I. The disposition of $\left[{ }^{3} \mathrm{H}\right]$ norepinephrine, $\left[{ }^{3} \mathrm{H}\right]$ dopamine and $\left[{ }^{3} \mathrm{H}\right] \mathrm{dopa}$ in various regions of the brain. J Neurochem 13:656669.

Gourdon J, Clos J, Coste C, Dainat J, Legrand J (1973) Comparative effects of hypothyroidism, hyperthyroidism and undernutrition on protein and nucleic acid contents of the cerebellum in the young rat. J Neurochem 21:861-871.

Hamburgh M, Flexner LB (1957) Biochemical and physiological differentiation during morphogenesis. XXI. Effect of hypothyroidism and hormone therapy on enzyme activities of the developing cerebral cortex of the rat. J Neurochem 1:279-288.

Hilgers J, Van Nie R, Ivanyi D, Hilkens J, Michalides R, de Moes J, Poort-Keesom R, Kroenzen V, von Diemling O, Kominami R, Holmes $R$ (1985) Genetic differences in BALB/c sublines. Curr Top Microbiol Immun 122:19-30.

Huber G, Matus A (1984) Differences in the cellular distributions of two microtubule-associated proteins, MAP1 and MAP2, in rat brain. J Neurosci 4:151-160.

Ireland RC, Kotarski MA, Johnston LA, Stadler U, Birkenmeier E, Kozak LP (1986) Primary structure of the mouse glycerol-3-phosphate dehydrogenase gene. J Biol Chem 261:11779-11785.

Isobe T, Nakajima T, Okuyama T (1977) Reinvestigation of extremely acidic proteins in bovine brain. Biochim Biophys Acta 494:222-232.

Jacobsson A, Stadler U, Glotzer MA, Kozak LP (1985) Mitochondrial uncoupling protein from mouse brown fat. J Biol Chem 260:1625016254.

Kozak LP (1972) Genetic control of alpha-glycerol-phosphate dehydrogenase in mouse brain. Proc Natl Acad Sci USA 69:3170-3174.

Kozak LP, Fisher M (1985) The molecular genetic analysis of snglycerol-3-phosphate dehydrogenase development in mouse cerebellum. In: Gene expression in the brain (Zomzely-Neurath C, Walker WA, eds), pp 173-204. New York: Wiley.

Kozak LP, Jensen JT (1974) Genetic and developmental control of multiple forms of $\mathrm{L}$-glycerol 3-phosphate dehydrogenase. J Biol Chem 299:7775-7781.

Laatsch RH (1962) Glycerol phosphate dehydrogenase activity of developing rat central nervous system. J Neurochem 9:487-492.

Legrand J (1979) Morphogenetic action of thyroid hormones. Trends Neurosci 2:234-236.

Leonard JL, Kaplan MM, Visser TJ, Silva JE, Larsen PR (1981) Cerebral cortex responds rapidly to thyroid hormones. Science 214:571573.

Levine S, Mullins RF (1966) Hormonal influences on brain organization in infant rats. Science 152:1585-1592.

Linn ECC (1977) Glycerol utilization and its regulation in mammals Annu Rev Biochem 46:765-795.
Malone MJ, Rosman NP, Szoke M, Davis D (1975) Myelination of brain in experimental hypothyroidism. An electron microscopic and biochemical study of purified myelin isolates. J Neurol Sci 26:1-11.

Matus A, Mughal S (1975) Immunohistochemical localization of S-100 protein in brain. Nature 258:746-748.

Messer A, Hatch K (1984) Persistence of cerebellar thymidine kinase in staggerer and hypothyroid mutants. J Neurogenetics 1:239-248.

Noguchi T, Sugisaki T (1984) Hypomyelination in the cerebrum of the congenitally hypothyroid mouse (hyt). J Neurochem 42:891-893.

Palay SL, Chan-Palay V (1974) Cerebellar cortex, cytology and organization, pp 288-321. New York: Springer.

Patel AJ, Smith RM, Kingsbury AE, Hunt A, Balázs R (1980) Effects of thyroid state on brain development: muscarinic, acetylcholine and GABA receptors. Brain Res 198:389-402.

Prochazka M, Kozak UC, Kozak LP (1989) A glycerol-3-phosphate dehydrogenase null mutant in BALB/c HcA mice. J Biol Chem 264: $4679-4683$.

Rastagi RB, Singhal RL (1979) Effect of neonatal hypothyroidism and delayed L-triiodethyronine treatment on behavioural activity and norepinephrine and Japamine biosynthetic systems in discrete regions of rat brain. Psychopharmacology 62:287-293.

Rosman NP, Malone MJ, Helfenstein M, Kraft E (1972) The effect of thyroid deficiency on myelination of brain. Neurology 22:99-106.

Sarlieve LL, Bouchon R, Koehl C, Neskovic NM (1983) Cerebroside and sulfatide biosynthesis in the brain of Snell dwarf mouse: effects of thyroxine and growth hormone in the early postnatal period. J Neurochem 40:1058-1062.

Schwark WS, Singhal RL, Ling GM (1971) Metabolic control mechanisms in mammalian systems. XIII. Thyroid hormone control of $\alpha$-glycerolphosphate dehydrogenase activity in rat cerebral cortex and cerebellum. Can J Physiol Pharmacol 49:598-607.

Schwark WS, Singhal RL, Ling GM (1972) Metabolic control mechanisms in mammalian systems. Regulation of key glycolytic enzymes in developing brain during experimental cretinism. J Neurochem 19: 1171-1182.

Sidman RL (1974) Cell-cell recognition in the developing central nervous system. In: The neurosciences third study program (Schmitt FO, Worden FG, eds), pp 743-758. Cambridge: MIT.

Silva JE, Rudas P (1990) Effects of congenital hypothyroidism on microtubule-associated protein-2-expression in the cerebellum of the rat. Endocrinology 126:1276-1282.

Smith DW, Blizzard RM, Wilkins L (1957) The mental prognosis in hypothyroidism of infancy and childhood. Pediatrics 19:1011-1022.

Smith RM, Patel AJ, Kingsbury AE, Hunt A, Balázs R (1980) Effects of thyroid state on brain development: $\beta$-adrenergic receptors and $5^{\prime}-$ nucleotidase. Brain Res 198:375-387. 